\title{
Administrative Policies to Reduce the Negative Impact of Variation Orders on Jordanian Construction Projects
}

\author{
Hamza A. M. Albtoosh, Taha M. Alkhamis* \\ Department of Chemical Engineering, Mutah University, Mutah-Karak, Jordan \\ Email: *alkhamis@mutah.edu.jo
}

How to cite this paper: Albtoosh, H. A. M., \& Alkhamis, T. M. (2021). Administrative Policies to Reduce the Negative Impact of Variation Orders on Jordanian Construction Projects. American Journal of Industrial and Business Management, 11, 329-340.

https://doi.org/10.4236/ajibm.2021.114021

Received: March 5, 2021

Accepted: April 11, 2021

Published: April 14, 2021

Copyright $\odot 2021$ by author(s) and Scientific Research Publishing Inc. This work is licensed under the Creative Commons Attribution International License (CC BY 4.0).

http://creativecommons.org/licenses/by/4.0/

\section{(c) (i) Open Access}

\begin{abstract}
Variation orders have been identified globally as important reasons for the poor performance of construction projects in most countries, which has affected their national economic growth. Several variation orders have been identified in the Jordanian construction industry; however, there is a paucity of information on the approaches to minimize their occurrence. Therefore, administrative practices to reduce the negative impact of variation orders in the construction sector in Jordan are highly required. To achieve the objective of the current study, the researchers used the quantitative approach to a structured questionnaire consisting of 10 administrative policies to reduce the negative impact of variation orders. A total of 161 questionnaires were collected against 250 questionnaires distributed among engineers in construction projects. According to the findings of the study, the top five policies for minimizing variation orders include: all involved parties require audit planning before works start on site; ensure that the drawings conform to the required specifications; the owner must be informed of the designs before bidding; checking the specifications required in the contract; effective communication between all parties concerned during the entire stages of the project. Moreover, proper planning before starting the project greatly contributes to reducing potential variation orders. The findings of this research, therefore, contribute to a pool of knowledge that will enable practitioners and researchers in the construction industry to develop effective strategies for minimizing variation orders.
\end{abstract}

\section{Keywords}

Administrative Policies, Variation Orders, Construction Industry, Project Management 


\section{Introduction}

Construction sector in Jordan is a vital base in improving the economic conditions of individuals and society. As reported by Oxford Business Group, the construction sector in Jordan witnessed improved growth in 2013 with expectations of continued growth in 2014. Loans granted in 2013 reached $\$ 5.76$ billion, which represents $21.5 \%$ of the credit for all professions, building accounted for the biggest part. The construction sector is the backbone of the economy in developed and developing countries. Jordan is one of the developing countries that depend on the construction sector in its economy. Variation orders are among the most prominent obstacles that negatively affect the development and growth of this sector.

Variation orders are often issued to correct or amend the original scope of work because changes during project creation are inevitable. Identifying the critical causes of variation orders and their impact on construction projects helps in identifying appropriate administrative policies to address them. Variation orders are considered one of the most common problems in construction projects in developing and developed countries. Jordan, as a developing country, continues to face the challenge of variation orders despite the development of construction project management methods. This study aims to identify the administrative policies that can reduce the negative impact of variation orders on Jordanian construction projects. The study targeted construction projects of all kinds, whether they are buildings, roads, infrastructure, or others. Thus, this study focuses on identifying the essential administrative policies that enable reducing variation orders in Jordanian construction projects.

\section{Literature Review}

\subsection{Construction Industry}

Researchers reported on how construction industries around the world are motivating economic growth mainly because of the contribution the sector provides to these countries' economies by providing the necessary infrastructure that will encourage other industries to expand (Ofori, 2012). Furthermore, construction industry is one of the major sectors contributing to job creation in most economies and is, therefore, a key component of many countries (Chileshe \& Yirenkyi-Fianko, 2012). Construction industry is one of the major sectors contributing to job creation in most economies. The construction industry also provides a source of development for other industries. In every country, the construction industry is needed to deliver physical consequences that help improve the country's social and economic needs. Additionally, it contributes to other sectors to provide economic growth in the country.

Sheer complexity of the construction projects and the diversity of the fields and activities involved have made them prone to many issues. Most of these issues arise during the construction process due to discrepancies in the drawings and contract documents. The construction industry, like other sectors, is faced 
with various problems due to different reasons' that variations and variation orders may be counterproductive, unless all participants find them collectively. It needs everyone to investigate the causes, results, and consequences of these orders and how they are structured and controlled. As part of the contract management process, variation orders are acceptable.

\subsection{Variation Orders}

Variation orders are popular in construction projects in many types (CII, 1994; Fisk, 1997; O’Brien, 1998; Ibbs et al., 2001). A variation involves not only the changes or conditions contributing to the work but also the changes to the working environment. It is one of the main problems facing the construction project during the implementation phase, which lead to project delays, cost overruns, and other adverse consequences (Memon, Rahman, \& Hasan, 2014). Variation order is a formal document specifying the improvements made between the owner and the contractor in the original agreement. The variation orders defined as the deviation encountered in any project from the basic contract or the mutually agreed scope of work at the time of contract (Keane, Sertyesilisik, \& Ross, 2010), which are due to various causes, some of them are predictable and others are not (Memon et al., 2014).

Oladapo (2007) reported that the key sources of variation orders are changes in specification and scope initiated mainly by project owners and their consultants. There are different reasons for variation orders that were identified in different studies, such as: Change in scope (Arain, Assaf, \& Pheng, 2004), Owner financial problems (Clough, Sears, Sears, Segner, \& Rounds, 2015; O’Brien, 1998), Obstructing the decision-making process (Sanvido, Grobler, Parfitt, Guvenis, \& Coyle, 1992; Gray \& Hughes, 2007), Lack of flexibility of the owner (Arain et al., 2004; Wang, 2000), The owner change the specifications (O'Brien, 1998), The consultant's change in design (Fisk \& Reynolds, 1988), Complexity of the design (Arain et al., 2004), Inadequate details of working drawings (Arain et al., 2004), causing variations in the project, Insufficient design (Fisk \& Reynolds, 1988; Force, 1990).

Mohammad, Ani, and Rakmat (2017) investigated the main effects of variation orders on projects and suggested that the effects are: the increase of project time, the increase in the project cost, the delay of logistics, the impact on the quality of the project, and the destruction and reconstruction of certain components. Moreover, variation orders have a direct impact on labor productivity whether it is individual, or group works. Changes in construction often lead to disruption which leads to workers' productivity degradation (Thomas \& Napolitan, 1995). Productivity is mostly influenced by variation orders because workforce should put more efforts, extra working hours and work overload and that is translated into extra costs (Hester, Kuprenas, \& Chang, 1991).

Therefore, it is necessary to follow administrative policies to control this problem from the beginning of planning the project until its completion. As specified by Arain and Pheng (2005), differences during the design phases can be 
minimized with due diligence.

Proper and well-structured management on the part of the owner is crucial for managing the process of variation orders (Günhan, Arditi, \& Doyle, 2007). Therefore, the owner is considered primarily responsible for the variation orders, and hence the first step to reducing variation orders in construction projects starts with the owner. Several recommendations for minimizing variation orders in the construction industry are reported by various studies. For example, the provision of appropriate full design site requirements would help to minimize the order of variance in the construction industry (Jarkas \& Haupt, 2015; Hayes, 2018), adequate preparation and interpretation of contract terms by the parties concerned prior to the start of the construction works (Nassar, 2017), employing highly experienced consultants and contractors (Le, 2019). In addition, the provision of appropriate funds, the correction of errors at the stage of project design and the removal of delay in tendering were identified as possible strategies for eliminating variation orders in the construction industry (Famiyeh, Amoatey, Adaku, \& Agbenohevi, 2017).

\section{Research Methodology}

In this study, the methodology adopted was a combination of literature review and questionnaire survey to find out the most effective administrative policies to reduce the impact of variation orders on construction projects in Jordan (Albtoosh, 2020). The first step in the research methodology was to collect data related to the problem of variation orders, and that was through a comprehensive literature review. It has been observed that there is a lack of research in this area. Figure 1 illustrates the main steps of the current study's methodology.

The questionnaire was divided into four main parts. First part sought to obtain basic information about the respondents, while the second part focused on the causes of the variation orders. The third part focused on the effects of variation orders. Finally, the fourth part focused on exploring administrative policies to reduce the negative impact of variation orders in Jordanian construction projects.

This study was organized in a four-step process. In the first step, theoretical studies were conducted to achieve the background and literature of the research. At this stage, the administrative policies to reduce the negative impact of variation orders were provided. In the second stage, based on a thorough review of the literature and five experts-judgments, 10 crucial administrative policies were placed in the questionnaire survey.

Experts tested the validity of the survey tool by giving some comments. It was taken to improve and ensure the validity of the questionnaire as a useful tool for collecting the data necessary for the study. Experts' comments include paraphrasing of some questions, suggesting addition of new questions to the study, deleting repetitive questions, and one expert suggested formulating some questions in the same meaning to examine reliability. 


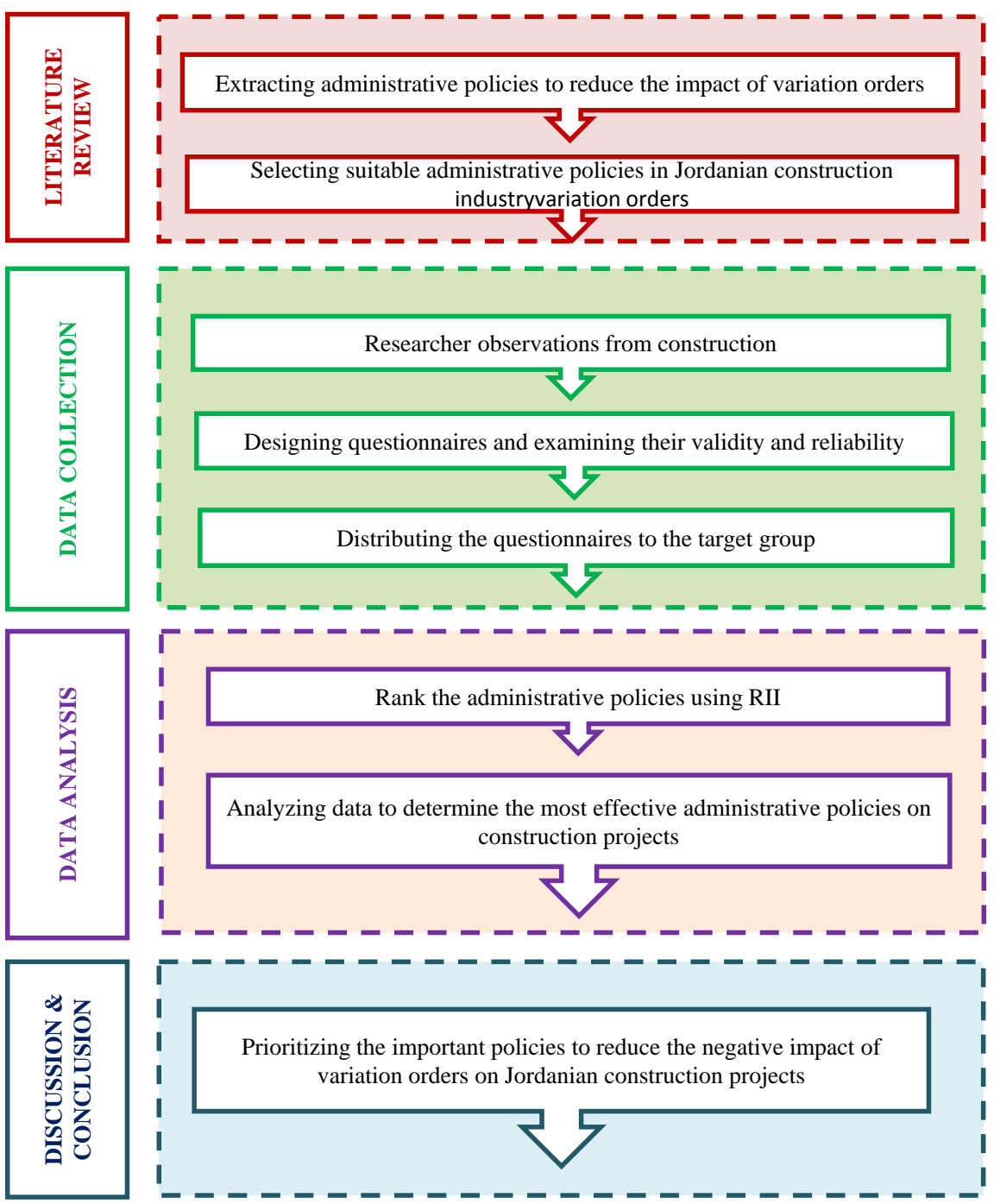

Figure 1. Flowchart of the research process (literature review, data collection, data analysis, discussion, and conclusion).

The respondents were requested to rank these policies on a five-point Likert scale, i.e. 5 for "Strongly Agree", 4 for "Agree", 3 for "Neutral", 2 for "Disagree", and 1 for "Strongly Disagree". In addition, the tools were distributed among the research units and then the field information was gathered. In the third step, while collecting the completed tools, the content analysis was carried out to analyze the questionnaire. Then, analysis of the data was carried out in the fourth step using SPSS ${ }^{\circledR}$ (Statistical Package for the Social Sciences) Version 26.0 and Microsoft Excel to ensure the accuracy of the results. Finally, the results were obtained and discussed to answer the research questions.

\section{Results, Analysis and Discussion}

The data of the current study were collected through a structured questionnaire targeting engineers working in Jordanian construction projects. A total of 250 forms were distributed to Jordanian construction projects. The collected number 
of questionnaires was 161 which is equivalent to a response rate of $64.4 \%$.

The respondents in the questionnaire as shown in Figure 2 consisted of civil engineers of about $64.0 \%$. Regarding their education level, most of them (about $74.5 \%$ ) hold a bachelor's degree. To assess the work experience of the respondents, the results confirmed that $(56.5 \%)$ of the participants have worked for at least ten years, which means that they have good experience to give confident answers to the research questions. In terms of respondent position, there are $19.90 \%$ project managers and $35.40 \%$ site engineers. In addition, the participants included contractors, consultants, and owners with $41.1 \%, 33.50 \%$ and $25.50 \%$ respectively.

The data collected from the questionnaire were analyzed using SPSS $^{\circledR}$ software version 26. First, before analyzing the data, one must verify the reliability of the data through the reliability test. The results of the reliability test as shown in Table 1 revealed that there is a strong reliability with a value of Cronbach's alpha equals 0.914. Data reliability is considered to be good when Cronbach alpha is more than 0.7 , which indicates that the data is suitable for further analysis (Wanjari \& Dobariya, 2016). In addition, construction reliability is acceptable, since the satisfied reliability value exceeds 0.7 as suggested by Yeung (2014). Table 1 presents a value of Cronbach's alpha equals 0.914 which is obtained from the analysis software.

\begin{tabular}{|c|c|c|c|}
\hline \multicolumn{2}{|c|}{ Level of Education } & \multicolumn{2}{|c|}{ Working Experience } \\
\hline $74.50 \%$ & $\begin{array}{l}\text { Diploma } \\
\text { Bachelor }\end{array}$ & Master \\
\hline
\end{tabular}

\begin{tabular}{|c|c|c|c|}
\hline \multicolumn{2}{|c|}{ Engineering Competency } & \multicolumn{2}{|c|}{ Type of Organization } \\
\hline $\begin{array}{l}11.8 \% \\
5.6 \% \\
16.1 \%\end{array}$ & $\begin{array}{l}\text { Civil } \\
\text { Architectural } \\
\text { Electrical } \\
\text { Mechanical } \\
\text { Others }\end{array}$ & $\chi_{33.5 \%}^{25.5 \%}$ & $\begin{array}{l}\text { Owner } \\
\text { Consultant } \\
\text { Contractor }\end{array}$ \\
\hline
\end{tabular}

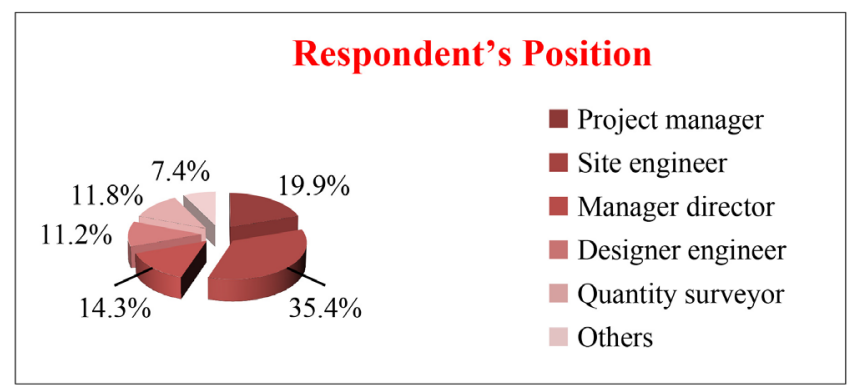

Figure 2. Policies versus participants percentages included contractors, consultants, and owners. 
Table 1. Cronbach's alpha value equal 0.914 .

\begin{tabular}{clcc}
\hline Code & Category & No. Items & Cronbach $\alpha$ \\
\hline AVO & $\begin{array}{l}\text { Administrative policies to reduce the negative } \\
\text { impact of variation orders }\end{array}$ & 10 & 0.914 \\
\hline
\end{tabular}

Through the questionnaire, the respondents were to give their opinion to rank the effectiveness of each of ten potential administrative policies to reduce variation orders in construction projects in Jordan. To measure the data from the questionnaire survey, a Likert scale of five ranking scales from 1 to 5 according to the level of contribution was used, where: 1 totally disagrees, 2 disagree, 3 neutral, 4 agree, 5 totally agree. The adopted scale allowed individuals to express their opinion on how much they strongly agreed with a particular statement or strongly disagreed with it (Mashwama, Aigbavboa, \& Thwala, 2016).

The relative significance index method was used to assess responses to the variables and items of the questionnaire. On the other hand, in construction research studies, the relative index method is used more frequently to quantify responses to questionnaire variables and items under study (Singh, \& Singh, 2017). The RII was calculated by using the following equation, as stated by (Enshassi, Mohamed, \& Abushaban, 2009; Megha \& Rajiv, 2013):

$$
\mathrm{RII}=\frac{\sum_{i=1}^{5} W_{i} X_{i}}{A \times N}
$$

where:

RII-Relative Importance Index;

$W$-Weighting given to each factor (1 to 5);

$X$-Frequency of response given for each item;

$A$-Highest weight (5 in this case);

$N$-Total number of respondents (161).

The results obtained, as presented in Table 2 summarized the values of mean, RII, and ranks for each of the policies.

The respondents in this study were divided into three main groups: owners, consultants, and contractors. Table 3 shows the results of the responses of each group which were analyzed separately and compared with each other.

The top five administrative policies to reduce variation orders in this study are; Audit planning required by all involved parties before works start on site (AVO1), Ensure that the drawings conform to the required specifications (AVO9), The owner must be informed of the designs before bidding (AVO10), Checking the specifications required in the contract (AVO5), and Effective communication between all parties concerned during the entire stages of the project (AVO6) as shown in Table 3.

The most effective policy for reducing variation orders according to the results of this study is AVO1, which ranked $1^{\text {st }}$ according to the overall ranking. Only contractors agreed with this result, while the owners and consultants 
Table 2. Summarized values of mean, RII, and ranks for each of the policies.

\begin{tabular}{|c|c|c|c|c|}
\hline Code & $\begin{array}{l}\text { Administrative Policies to Reduce the } \\
\text { Negative Impact of Variation Orders }\end{array}$ & Mean & RII & Rank \\
\hline AVO1 & $\begin{array}{l}\text { Audit planning is required by all involve parties before works } \\
\text { start on site. }\end{array}$ & 4.6273 & 0.9255 & 1 \\
\hline AVO9 & Ensure that the drawings conform to the required specifications. & 4.6087 & 0.9217 & 2 \\
\hline AVO10 & The owner must be informed of the designs before bidding. & 4.6025 & 0.9205 & 3 \\
\hline AVO5 & Checking the specifications required in the contract. & 4.5963 & 0.9193 & 4 \\
\hline AVO6 & $\begin{array}{l}\text { Effective communication between all parties concerned during } \\
\text { the entire stages of the project. }\end{array}$ & 4.5652 & 0.9130 & 5 \\
\hline AVO3 & $\begin{array}{l}\text { Carry out details site investigation including detail soil } \\
\text { investigation during tendering stage. }\end{array}$ & 4.5280 & 0.9056 & 6 \\
\hline AVO4 & $\begin{array}{l}\text { Commitment to the percentages specified in the contract for the } \\
\text { value of the variable orders. }\end{array}$ & 4.4907 & 0.8981 & 7 \\
\hline AVO2 & Providing the project site with infrastructure services. & 4.4348 & 0.8870 & 8 \\
\hline AVO8 & Prepare the contract document before tendering stage. & 4.4224 & 0.8845 & 9 \\
\hline AVO7 & Forecast unforeseen situations before tendering. & 4.4099 & 0.8820 & 10 \\
\hline
\end{tabular}

Table 3. A comparison between the respondent and their different ranks.

\begin{tabular}{ccccccccc}
\hline Administrative & \multicolumn{2}{c}{ Overall } & \multicolumn{2}{c}{ Owners } & \multicolumn{2}{c}{ Consultants } & \multicolumn{2}{c}{ Contractors } \\
\hline Policies & RII & Rank & RII & Rank & RII & Rank & RII & Rank \\
\hline AVO1 & 0.9255 & 1 & 0.9317 & 3 & 0.9259 & 3 & 0.9212 & 1 \\
AVO9 & 0.9217 & 2 & 0.9171 & 5 & 0.9407 & 1 & 0.9091 & 3 \\
AVO10 & 0.9205 & 3 & 0.9463 & 1 & 0.9333 & 2 & 0.8939 & 6 \\
AVO5 & 0.9193 & 4 & 0.9268 & 4 & 0.9111 & 4 & 0.9212 & 1 \\
AVO6 & 0.9130 & 5 & 0.9415 & 2 & 0.9037 & 5 & 0.9030 & 4 \\
AVO3 & 0.9056 & 6 & 0.9268 & 4 & 0.9000 & 6 & 0.8970 & 5 \\
AVO4 & 0.8981 & 7 & 0.9024 & 7 & 0.8741 & 8 & 0.9152 & 2 \\
AVO2 & 0.8870 & 8 & 0.9073 & 6 & 0.8852 & 7 & 0.8758 & 7 \\
AVO8 & 0.8845 & 9 & 0.9268 & 4 & 0.8852 & 7 & 0.8576 & 8 \\
AVO7 & 0.8820 & 10 & 0.9073 & 6 & 0.8370 & 9 & 0.9030 & 4 \\
\hline
\end{tabular}

agreed with each other to place it in third place. Planning and reviewing documents for construction projects is one of the most important strategies that contribute to improving project performance as it reduces potential problems during the implementation period.

The second effective policy is (AVO9) was ranked as the first effective policy on the viewpoint of the consultant. On the other hand, it ranked by owners and contractors as $5^{\text {th }}$ and $3^{\text {rd }}$, respectively. One of the most common problems in construction projects is that the drawings do not match the required specifications, so they must be checked before submitting the bid. 
The third policy (AVO10) was ranked by the owners, consultants, and contractors to be the $1^{\text {st }}, 2^{\text {nd }}$, and $6^{\text {th }}$, respectively. One of the main reasons that lead to change orders in construction projects is the additional work at the request of the owner, which is the result of the owner not being aware of the designs prior to the assignment. Owners being aware of the design alone do not stop them from requesting variation orders. In fact, owners must be made to understand details of the drawings and sign off before the project commences.

The owners and consultants in this study agreed to rank (AVO5) as the fourth policy in its effectiveness for reducing variation orders, while it ranked first in its effectiveness from the contractors' point of view. Changing specifications in construction projects during the implementation phase is a common occurrence in construction projects because of duplicating specifications from previous projects. Therefore, specifications must be determined based on the requirements of each project and verified before the project is referred.

For the fifth policy, only the consultants corresponded to the overall ranks. Owners and contractors ranked it $2^{\text {nd }}$ and $4^{\text {th }}$, respectively. The nature of work in construction projects requires teamwork, which effectively contributes to the project's success in achieving its goals. Therefore, effective communication between all stakeholders during the entire project phases reduces the potential causes for variation orders to occur.

The results demonstrate the awareness of all parties in construction projects to the importance of administrative policies and their effectiveness in reducing variation orders during the implementation stages.

The current study is considered one of the studies that search about the solutions of variation orders in Jordanian construction projects, as most of the studies search about the causes and effects of variation orders.

Most administrative policies for minimizing variation orders are in the early stages of the project life cycle, which are the responsibility of the owner. Therefore, it is necessary to focus on this stage and give it the time and cost to implement it with high efficiency. The construction projects in Jordan are clearly suffering from problems in preparation of the project in its early stages for various reasons. The most prominent reason is the inefficiency of the preparation team. The other reason is the failure to give enough time for the preparation phase, and the last reason is the possible wrong choice of the design team.

\section{Conclusion}

A general conclusion of this study reveals a lack in research about administrative policies to reduce variation orders and their negative impacts in Jordanian construction projects. Therefore, it was difficult to find reported studies about administrative polices to compare with our findings (Albtoosh, 2020). However, our results reveal the following specific conclusions:

1) The study clearly shows that it is beneficial for the owner to be cognizant of the negative impacts of numerous change orders during construction and to be 
directly involved in the design stage.

2) The most three effective administrative policies to reduce the negative impact of variation orders are: All involved parties require audit planning before works start on site; Ensure that the drawings conform to the required specifications; and The owner must be informed of the designs before bidding.

3) Proper planning before starting the project greatly contributes to reducing potential variation orders.

4) Most of the respondents agreed in defining policies to reduce variation orders.

5) Constructability reviews help minimize the occurrence of design flaws that lead to variation orders, while value engineering ensures that the most economical solutions are used without sacrificing quality and function.

\section{Recommendations}

The following recommendations were derived from the results of this research that has been discussed in addition to the above key conclusions:

1) The owner must choose the designer with sufficient experience in the field of the project. Furthermore, the designer must be given enough time to prepare the designs with the required details.

2) Before starting the design, the project objectives must be clearly defined devoid of any ambiguities, which thus reduce additional work by the owner during implementation.

3) It is necessary to consult with the consulting office during the design phase to reduce design errors.

4) A comprehensive table should be prepared for detailed specifications of the project materials and their cost.

5) The owner must ensure that the materials are available with the required specifications in the local market to avoid changing the material specifications during the implementation phase.

6) Competencies and professional history should be the primary condition to choose the contractors and not the financial bidding offer.

7) After selecting the contractor, all parties (owner, designer, consultant, and contractor) must meet to review all documents and agree on every detail before signing the final agreement which will reduce the number of variation orders.

8) The choice of consultant must be based on his experience, competency, leadership, and knowledge of the regulations and the basic principles of the construction projects.

\section{Acknowledgements}

The authors wish to thank Professor Bassam Mahasneh and Miss Leen alkhamis for proofreading the manuscript.

\section{Conflicts of Interest}

The authors declare no conflicts of interest regarding the publication of this paper. 


\section{References}

Albtoosh, H. A. M. (2020). Tenders' Administration Policies Improvement on Reducing Negative Impact of Variation Orders on Construction Projects. MS Thesis, Jordan: Mutah University.

Arain, F. M., \& Pheng, L. S. (2005). The Potential Effects of Variation Orders on Institutional Building Projects. Facilities, 23, 496-510.

Arain, F. M., Assaf, S., \& Pheng, L. S. (2004). Causes of Discrepancies between Design and Construction. Architectural Science Review, 47, 237-249. https://doi.org/10.1080/00038628.2000.9697530

Chileshe, N., \& Yirenkyi-Fianko, A. B. (2012). An Evaluation of Risk Factors Impacting Construction Projects in Ghana. Journal of Engineering, Design and Technology, 10, 306-329. https://doi.org/10.1108/17260531211274693

CII (1994). Project Change Management. Special Publication 43-1, Austin, TX: Construction Industry Institute, University of Texas at Austin.

Clough, R. H., Sears, G. A., Sears, S. K., Segner, R. O., \& Rounds, J. L. (2015). Construction Contracting: A Practical Guide to Company Management. Hoboken, NJ: John Wiley \& Sons.

Enshassi, A., Mohamed, S., \& Abushaban, S. (2009). Factors Affecting the Performance of Construction Projects in the Gaza Strip. Journal of Civil Engineering and Management, 15, 269-280. https://doi.org/10.3846/1392-3730.2009.15.269-280

Famiyeh, S., Amoatey, C. T., Adaku, E., \& Agbenohevi, C. S. (2017). Major Causes of Construction Time and Cost Overruns. Journal of Engineering, Design and Technology, 15, 181-198. https://doi.org/10.1108/JEDT-11-2015-0075

Fisk, E. R. (1997). Construction Project Administration (5th ed.). Upper Saddle River, NJ: Prentice Hall.

Fisk, E. R., \& Reynolds, W. D. (1988). Construction Project Administration (10th ed.). USA: Wiley.

Construction Industry Institute Cost/Schedule Controls Task Force (1990). The Impact of Changes on Construction Cost and Schedule (Vol. 6). Austin, TX: Institute, University of Texas at Austin.

Gray, C., \& Hughes, W. (2007). Building Design Management. London: Routledge. https://doi.org/10.4324/9780080500409

Günhan, S., Arditi, D., \& Doyle, J. (2007). Avoiding Change Orders in Public School Construction. Journal of Professional Issues in Engineering Education and Practice, 133, 67-73. https://doi.org/10.1061/(ASCE)1052-3928(2007)133:1(67)

Hayes, J. (2018). The Theory and Practice of Change Management. UK: Palgrave.

Hester, W., Kuprenas, J., \& Chang, T. (1991). Construction Changes and Change Orders, Source Document 66. Austin, TX: Construction Industry Institute.

Ibbs, C. W., Wong, C. K., \& Kwak, Y. H. (2001). Project Change Management System. Journal of Management in Engineering, 17, 159-165.

https://doi.org/10.1061/(ASCE)0742-597X(2001)17:3(159)

Jarkas, A. M., \& Haupt, T. C. (2015). Major Construction Risk Factors Considered by General Contractors in Qatar. Journal of Engineering, Design and Technology, 13, 165-194. https://doi.org/10.1108/JEDT-03-2014-0012

Keane, P., Sertyesilisik, B., \& Ross, A. D. (2010). Variations and Change Orders on Construction Projects. Journal of Legal Affairs and Dispute Resolution in Engineering and Construction, 2, 89-96. https://doi.org/10.1061/(ASCE)LA.1943-4170.0000016 
Le, N. T. K. (2019). Identification of Risk Factors, Success Practices, and Feasibility of the Best Value Approach Application to Improve Construction Performance in Vietnam and Other Developing Countries. Tempe, AZ: Arizona State University.

Mashwama, X., Aigbavboa, C., \& Thwala, D. (2016). Investigation of Construction Stakeholders' Perception on the Effects \& Cost of Construction Dispute in Swaziland. Procedia Engineering, 164, 196-205. https://doi.org/10.1016/j.proeng.2016.11.610

Megha, D., \& Rajiv, B. (2013). A Methodology for Ranking of Causes of Delay for Residential Construction Projects in Indian Context. International Journal of Emerging Technology and Advanced Engineering, 3, 396-404.

Memon, A. H., Rahman, I. A., \& Hasan, M. F. A. (2014). Significant Causes and Effects of Variation Orders in Construction Projects. Research Journal of Applied Sciences, Engineering and Technology, 7, 4494-4502. https://doi.org/10.19026/rjaset.7.826

Mohammad, N., Ani, A. I. C., \& Rakmat, R. A. O. (2017). Causes and Effects of Variation Orders in the Construction of Terrace Housing Projects: A Case Study in the State of Selangor, Malaysia. International Journal of Supply Chain Management, 6, 226-232.

Nassar, S. R. (2017). Management of Variation Orders in Gaza Strip: Impacts and Minimization. Gaza: The Islamic University of Gaza.

O’Brien, W. J. (1998). Capacity Costing Approaches for Construction Supply-Chain Management. Ph.D. thesis, California: Sanford University.

Ofori, G. (2012). Developing the Construction Industry in Ghana: The Case for a Central Agency (pp. 3-18). A Concept Paper Prepared for Improving the Construction Industry in Ghana. Singapore: National University of Singapore.

Oladapo, A. (2007). A Quantitative Assessment of the Cost and Time Impact of Variation Orders on Construction Projects. Journal of Engineering, Design and Technology, 5, 35-48. https://doi.org/10.1108/17260530710746597

Sanvido, V., Grobler, F., Parfitt, K., Guvenis, M., \& Coyle, M. (1992). Critical Success Factors for Construction Projects. Journal of Construction Engineering and Management, 118, 94-111. https://doi.org/10.1061/(ASCE)0733-9364(1992)118:1(94)

Singh, A. P., \& Singh, R. (2017). Ranking Delay, Cost, Quality Factors for Project Success in Real Estate Companies. International Journal of Latest Trends in Engineering and Technology, 8, 273-287. https://doi.org/10.21172/1.841.45

Thomas, H. R., \& Napolitan, C. L. (1995). Quantitative Effects of Construction Changes on Labor Productivity. Journal of Construction Engineering and Management, 121, 290-296. https://doi.org/10.1061/(ASCE)0733-9364(1995)121:3(290)

Wang, Y. (2000). Coordination Issues in Chinese Large Building Projects. Journal of Management in Engineering, 16, 54-61. https://doi.org/10.1061/(ASCE)0742-597X(2000)16:6(54)

Wanjari, S. P., \& Dobariya, G. (2016). Identifying Factors Causing Cost Overrun of the Construction Projects in India. Sādhanā, 41, 679-693. https://doi.org/10.1007/s12046-016-0498-3

Yeung, P. (2014). SPSS Survival Manual. A Step by Step Guide to Data Analysis Using IBM SPSS [Book Review]. Aotearoa New Zealand Social Work, 26, 92. 